\title{
The microRNA expression profile in rat lung tissue early after burn injury
}

\author{
Donghai Zhang, M.D., ${ }^{1}$ Yang Chang, M.D., ${ }^{2}$ Shaofang Han, M.D., ${ }^{2}$ Longlong Yang, M.D., ${ }^{2}$ \\ Quan Hu, M.D., ${ }^{2}$ Yonghui Yu, M.D., ${ }^{2}$ Lingying Liu, M.D., ${ }^{2}$ Jiake Chai, M.D. ${ }^{2}$
}

${ }^{1}$ Department of Postgraduates, Chinese PLA Medical School, the Chinese PLA General Hospital, Beijing-People's Republic China ${ }^{2}$ Department of Burn and Plastic Surgery, the First Affiliated Hospital of the PLA General Hospital, Beijing-People's Republic China

\begin{abstract}
BACKGROUND: Severe burn causes acute lung injury in many victims, but the related mechanisms have been barely investigated. microRNAs (miRNAs) important regulators in numerous physiological and pathophysiological process. However, the roles of miRNAs in burn lung injury are untested.

METHODS: Six healthy male Sprague-Dawley rats were randomly assigned into burn and sham groups. Lung injury was evaluated by hematoxylin and eosin (HE) staining at $24 \mathrm{~h}$ after injury. Differentially expressed miRNAs were determined by array hybridization and verified by real-time quantitative polymerase chain reaction (RT-qPCR). Bioinformatics analysis was undertaken to predict the target genes. Gene Ontology and Kyoto Encyclopedia of Genes and Genomes databases were employed to identify potentially related biological processes and pathways, respectively. Neutrophil infiltration and apoptosis of the lung were confirmed by immunohistochemical staining of myeloperoxidase (MPO) and terminal deoxynucleotidyl transferase-mediated dUTP nick-end labeling (TUNEL).
\end{abstract}

RESULTS: HE sections showed obvious lung injury, and 21 upregulated and three downregulated miRNAs were detected. Target genes of these miRNAs were most highly enriched in inflammation and apoptosis related GO biological processes and pathways. Inflammation and apoptosis were confirmed by MPO and TUNEL staining.

CONCLUSION: The differentially expressed miRNAs most likely participate in burn-induced lung injury by being involved in inflammation and apoptosis.

Keywords: Apoptosis; burn; inflammation; lung injury/ARDS; microRNA.

\section{INTRODUCTION}

Patients with extensive burns are at high risk of developing acute respiratory distress syndrome (ARDS) ${ }^{[1]}$ Approximately one-third of patients with burns who require mechanical ventilation on admission develop ARDS with severity correlating with mortality. ${ }^{[2,3]}$ Despite ongoing research, ARDS diagnosis remains largely based on clinical manifestations, whereas treatment focuses primarily on mechanical ventilation. ${ }^{[4,5]}$ Biomarkers for application in clinical laboratory testing and pharmacological management are lacking. ${ }^{[5,6]}$

MicroRNAs (miRNAs) are small (approximately 22 nucleo- tides) noncoding RNAs that regulate gene expression. They do this by binding to mRNA 3'-untranslated regions, causing translational repression or degradation of target mRNAs. $[5,7,8]$ The miRBase database ${ }^{[9]}$ includes 2588 entries of mature human miRNAs that participate in various physiological and pathophysiological processes. ${ }^{[7,10]}$ Studies have elucidated the changes in miRNA expression that occur during ARDS, along with the pathogenic roles of certain miRNAs under various conditions. ${ }^{[1-22]}$ However, little is known about the relationship between these changes and lung injury in patients with burns.

We hypothesized that specific miRNAs are involved in the initiation of lung injury in patients with extensive burns. Thus,

Cite this article as: Zhang D, Chang Y, Han S, Yang L, Hu Q, Yu Y, et al. The microRNA expression profile in rat lung tissue early after burn injury. Ulus Travma Acil Cerrahi Derg 2018;24:191-198.

Address for correspondence: Jiake Chai, M.D.

5I Fucheng Road, Haidian District, Beijing 100048, China Beijing, People's Republic China

Tel: +86 1066867972 E-mail: cjk304@I26.com

Ulus Travma Acil Cerrahi Derg 2018;24(3):191-198 DOI: 10.5505/tjtes.2018.98I23 Submitted: 20.11.2017 Accepted: 07.03.2018 Online: 09.05.2018

Copyright 2018 Turkish Association of Trauma and Emergency Surgery 
the aim of this study was to determine the expression profile of miRNAs in rat lung early after burn lesion.

\section{MATERIALS AND METHODS}

\section{Animal Care}

Six healthy male Sprague-Dawley rats (180-220 g) were purchased from Peking University Laboratory Animal Center. They were then acclimatized for I week each in single cage at $22-24^{\circ} \mathrm{C}$ with $12 \mathrm{~h}$ day/night cycles, and food and water ad libitum. The experimental protocol adhered to the Guide for Care and Use of Laboratory Animals by the Chinese Academy of Science. Approval was granted by the Institutional Animal Care \& Use Committee of the First Affiliated Hospital of the People's Liberation Army General Hospital [SYXK(JUN)20 I 2-00 I4] (Beijing, China).

\section{Animal Model}

Three rats each were randomly assigned into sham and burn groups and anesthetized before being injured and sacrificed. The $30 \%$ total body surface area full-thickness burn rat model was built as previously described. ${ }^{[23]}$ Briefly, the rats in burn group had their backs shaven and then immersed in $94^{\circ} \mathrm{C}$ water for $12 \mathrm{~s}$. Anti-shock therapy was administrated as sodium chloride $0.9 \%$ (normal saline) $40 \mathrm{~mL} / \mathrm{kg}$ by intraperitoneal injection. Wounds were treated with $1 \%$ tincture iodine and left open. For the sham group, the only difference in process was that the immersion temperature of the water was $37^{\circ} \mathrm{C}$ instead of $94^{\circ} \mathrm{C}$.

\section{Sample Collection}

The rats were sacrificed under anesthesia with tribromoethanol (Avertin ${ }^{\circledR}, 300 \mathrm{mg} / \mathrm{kg}$, Sigma, USA) by drawing blood from the abdominal aorta with $10-\mathrm{mL}$ syringes at $24 \mathrm{~h}$ after injury. Their tracheas were exposed and clamped immediately after blood was drawn. Whole lungs were harvested via midline sternotomy, and the lobes separated one by one. The left lung was fixed in formalin and the right lung accessory lobe of was placed in liquid nitrogen immediately.

\section{Hematoxylin and Eosin (HE) Staining}

After fixing for at least $24 \mathrm{~h}$, left lung tissue was embedded with paraffin and cut into 5 - $\mu \mathrm{m}$-thick sections. The sections were then deparaffinized in dimethylbenzene, rehydrated, and stained with HE before observation under a light microscope (Leica, Germany).

\section{Immunochemistry Staining}

Myeloperoxidase (MPO) immunochemistry staining was performed with MPO-specific antibody (Abcam, Cambridge, $M A)$ to detect neutrophil sequestration as per the manufacture's instruction. Apoptosis was determined with terminal deoxynucleotidyl transferase-mediated dUTP nick-end labeling (TUNEL). The positivity rates for MPO and TUNEL staining were determined.
RNA isolation, labeling, array hybridization, and data analysis These procedures were conducted by Kangchen Biotech Inc. (Shanghai, China) in accordance with the relevant manufacturer's instructions. Briefly, total RNA was isolated using TRIzol (Invitrogen, Grand Island, NY) and purified with RNeasy mini kit (QIAGEN, Valencia, CA). RNA quality and quantity was measured using nanodrop spectrophotometer ND-1000 (Nanodrop Technologies, Madison, WI) and integrity determined by gel electrophoresis. RNA labeling and array hybridization was undertaken following Exiqon's instructions (Exiqon, Vedbaek, Denmark). After quality control, the miRCURY'TM $\mathrm{Hy} 3^{\mathrm{TM}} / \mathrm{Hy} 5^{\mathrm{TM}}$ Power labeling kit (Exiqon) was used for miRNA labeling. $\mathrm{Hy} 3^{\mathrm{TM}}$-labeled samples were hybridized on the miRCURYTM LNA Array (v.19.0) (Exiqon). The slides were scanned using the Axon GenePix 4000B microarray scanner (Axon Instruments, Foster City, CA), and images then imported into GenePix Pro 6.0 software (Axon) for grid alignment and data extraction. Replicated miRNAs were averaged and miRNAs with intensities $\geq 30$ in all samples were chosen for calculating the normalization factor. Expressed data were normalized using the median normalization. After normalization, significant differentially expressed miRNAs between two groups were identified through fold change $(>2$ or $<0.5)$ and $p$-value $(<0.05)$.

\section{Real-Time Quantitative Polymerase Chain Reaction (RT-qPCR)}

To validate the array result, both the upregulated and downregulated miRNAs with the highest fold change were selected for RT-qPCR. Prepared RNAs were reverse transcribed into cDNA with Gene Amp PCR System 9700 (Applied Biosystems, Forster City, CA). RT-qPCR was performed with $S_{Y B R}{ }^{\circledR}$ Green qPCR master mix (Arraystar, Rockville, MD) by using ViiA 7 Real-time PCR System (Applied Biosystems). The primers used for amplification were rnomiR-664-I-5p (forward: 5'-GGCTGGCTGGGGAAAA-3'; reverse: 5'-GTGCGTGTCGTGGAGTCG-3'); rno-miR-2223p (forward: 5'-GGGAGCTACATCTGGCTA-3'; reverse: 5'-TGCGTGTCGTGGAGTC-3') and U6 (forward: 5'-GCT TCGGCAGCACATATACTAAAAT-3'; reverse: 5'-CGCTTC ACGAATTTGCGTGTCAT-3'). The thermal conditions for RT-qPCR were $95^{\circ} \mathrm{C}$ for $10 \mathrm{~min}$, followed by 40 cycles of $95^{\circ} \mathrm{C}$ for $10 \mathrm{~s}$ and $60^{\circ} \mathrm{C}$ for $60 \mathrm{~s}$. RNA expression levels were evaluated by the comparative threshold cycle $(\Delta \mathrm{C} t)$ method. U6 RNA was used as the endogenous reference.

\section{Bioinformatics Analysis}

Bioinformatics analysis was conducted by GMINIX Informatics Co., Ltd. (Shanghai, China). Targetscan (www.targetscan.org) and miRanda (www.microrna.org) databases were used for target prediction. Significantly enriched biological processes and pathways were analyzed with Gene Ontology (GO) and Kyoto Encyclopedia of Genes and Genomes (KEGG) Pathway Databases. 

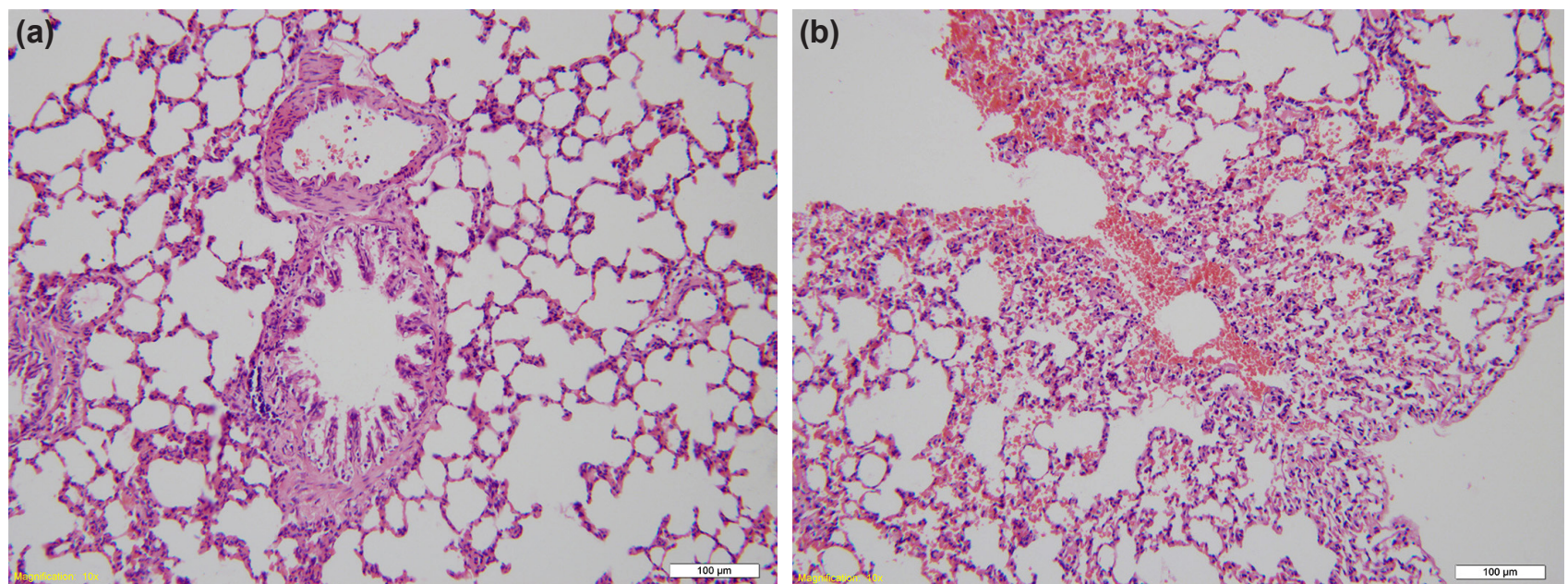

Figure 1. HE staining of lung tissue. (a) Is the sham group. (b) Is the burn group. The original magnification was $10 \times 10$. The scale bar was $100 \mu \mathrm{m}$.

\section{Statistical Analysis}

Array data were analyzed with random variance model t-test. Fisher's exact test was applied to identify significantly enriched biological processes and pathways, and false discovery rate was used to correct the $\mathrm{p}$ values. $\Delta \Delta \mathrm{Ct}$ of each miRNA validated by RT-qPCR between two groups was compared using t-test. Differences were considered significant at a $\mathrm{p}$-value of $<0.05$.

\section{RESULTS}

\section{Lung Injury Was Obvious in this Rat Model}

In the sham group, the general structure of the lung tissue was normal i.e., the alveolar space was clear, the alveolar septum was of regular thickness, and there was no significant leukocyte infiltration. In contrast, the burn group had significant histological changes featuring hyaline membrane formation, hemorrhage, alveolar septal thickening, and slight edema (Fig. I).

\section{miRNAs Expressed Differentially in}

\section{Burn-Induced Lung Injury}

According to the predefined criteria involving fold change (>2 or $<0.5)$ and $p$-value (<0.05), 24 differentially expressed miRNAs were filtrated (Table I). Of these, 2I were upregulated and three were downregulated in the lung tissues of rats with burns. The expressions of rno-miR-222-3p and rno-miR664-I-5p determined with RT-qPCR were in accordance with the microarray data (Fig. 2).

\section{Bioinformatics Analysis Highlighted Inflammation and Apoptosis Related GO Biological Processes and Pathways}

There were 1846 genes predicted as targets for the 24 differentially expressed miRNAs, including eukaryotic translation initiation factor 2 subunit gamma (Eif2s3x), Rac/Cdc42 guanine nucleotide exchange factor 6 (Arhgef6), G proteincoupled receptor I43 (Gprl43), and membrane magnesium

Table I. Differentially expressed miRNAs in rat lung tissue post-burns

\begin{tabular}{lcc}
\hline miRNA & Fold change $^{*}$ & $\mathbf{p}$ \\
\hline rno-miR-222-3p & 4.88 & 0.020 \\
rno-miR-429 & 4.16 & 0.025 \\
rno-miR-503-3p & 4.04 & 0.016 \\
rno-miR-22I-3p & 3.59 & 0.043 \\
rno-miR-106b-5p & $3.5 I$ & 0.024 \\
rno-miR-34c-5p & $3.5 I$ & 0.046 \\
rno-miR-24-2-5p & 3.48 & 0.031 \\
rno-miR-33I-3p & 3.48 & 0.044 \\
rno-miR-I-3p & 3.47 & 0.002 \\
rno-miR-339-5p & 3.47 & 0.048 \\
rno-miR-96-5p & 3.38 & 0.042 \\
rno-miR-674-5p & 3.18 & 0.021 \\
rno-miR-379-5p & 3.13 & 0.013 \\
rno-miR-99b-5p & 3.08 & 0.028 \\
rno-miR-672-5p & 3.05 & 0.028 \\
rno-miR-423-3p & 2.94 & 0.037 \\
rno-miR-I35a-5p & 2.93 & 0.011 \\
rno-miR-376a-3p & 2.6 & 0.049 \\
rno-miR-488-5p & 2.41 & 0.034 \\
rno-miR-190a-3p & 2.07 & 0.036 \\
rno-miR-4II-5p & 0.05 & 0.037 \\
rno-let-7d-5p & 0.36 \\
rno-miR-I9b-I-5p & \\
rno-miR-664-I-5p & & \\
\hline
\end{tabular}

*Fold change $>$ I, upregulated; fold change $<1$, down-regulated. The $\mathrm{p}$-value was calculated with random variance model t-test. miRNAs: MicroRNAs. 


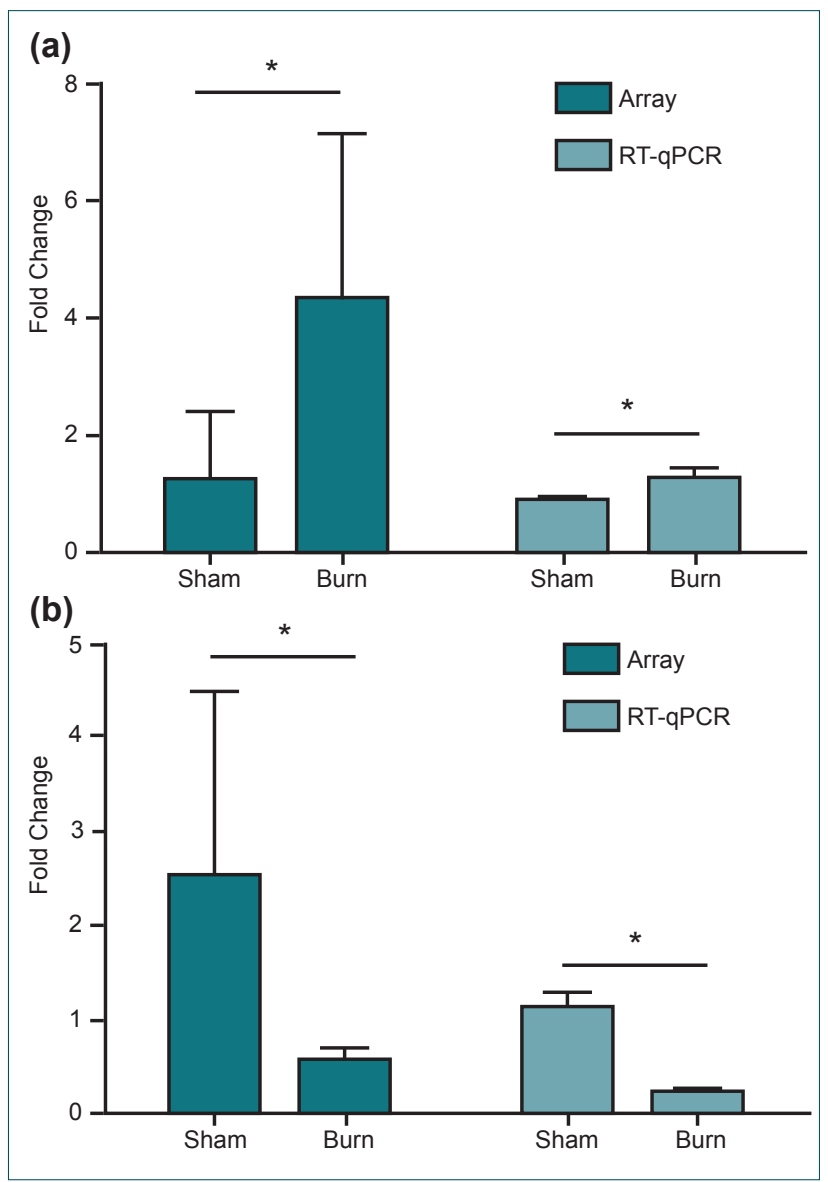

Figure 2. The fold change of the two miRNAs selected for validation. (a) Is the rno-miR-222-3p. (b) Is the rno-miR-664-1-5p. *Comparison between the two groups using t-test, $p<0.05$.

transporter I (Mmgtl), etc. These genes were significantly enriched in $548 \mathrm{GO}$ biological processes and in 89 pathways. GO biological processes with an enrichment score $>5$ and pathways with a $\mathrm{p}$-value of $<0.01$ were filtered. Then, the less related items such as mechanosensory behavior, satellite cell maintenance involved in skeletal muscle regeneration, and cerebral cortex tangential migration in GO biological processes as well as olfactory transduction, dilated cardiomyopathy, and malaria in pathways were ruled out. The remaining items were characterized by inflammation-related and apoptosis-related GO biological processes and pathways. Some of the most related GO biological processes items are listed in Figure 3 and ordered by the enrichment score. The most related pathways are listed in Figure 4 and ordered by-LgP.

\section{Apoptosis and Inflammation Condition in the Lung} Inflammation represented by neutrophil infiltration and apoptosis in the lung tissue were verified by immunochemistry. The positive rates of TUNEL and MPO in the burn group were significantly higher than in the control group. This indicated that the burn had caused conspicuous neutrophil infiltration and apoptosis in the lung (Fig. 5).

\section{DISCUSSION}

Several studies ${ }^{[1-22]}$ have revealed the miRNA expression profile of ARDS lung tissue from different conditions including radiation-induced injury in rat lung, oleic acid-induced acute lung injury and cardiopulmonary bypass-induced acute lung injury. However, to the best of our knowledge, no one has investigated the miRNA expression profile in lung tissue after extensive burns. The present study demonstrated that burn-induced lung injury in rats was associated with aberrant miRNA expression.

After a severe skin scald, histological changes characterized by hyaline membrane formation, hemorrhage, alveolar septal thickening, and edema were observed in HE-stained specimens. Array hybridization of lung tissue samples detected 21 upregulated and three downregulated miRNAs. The most

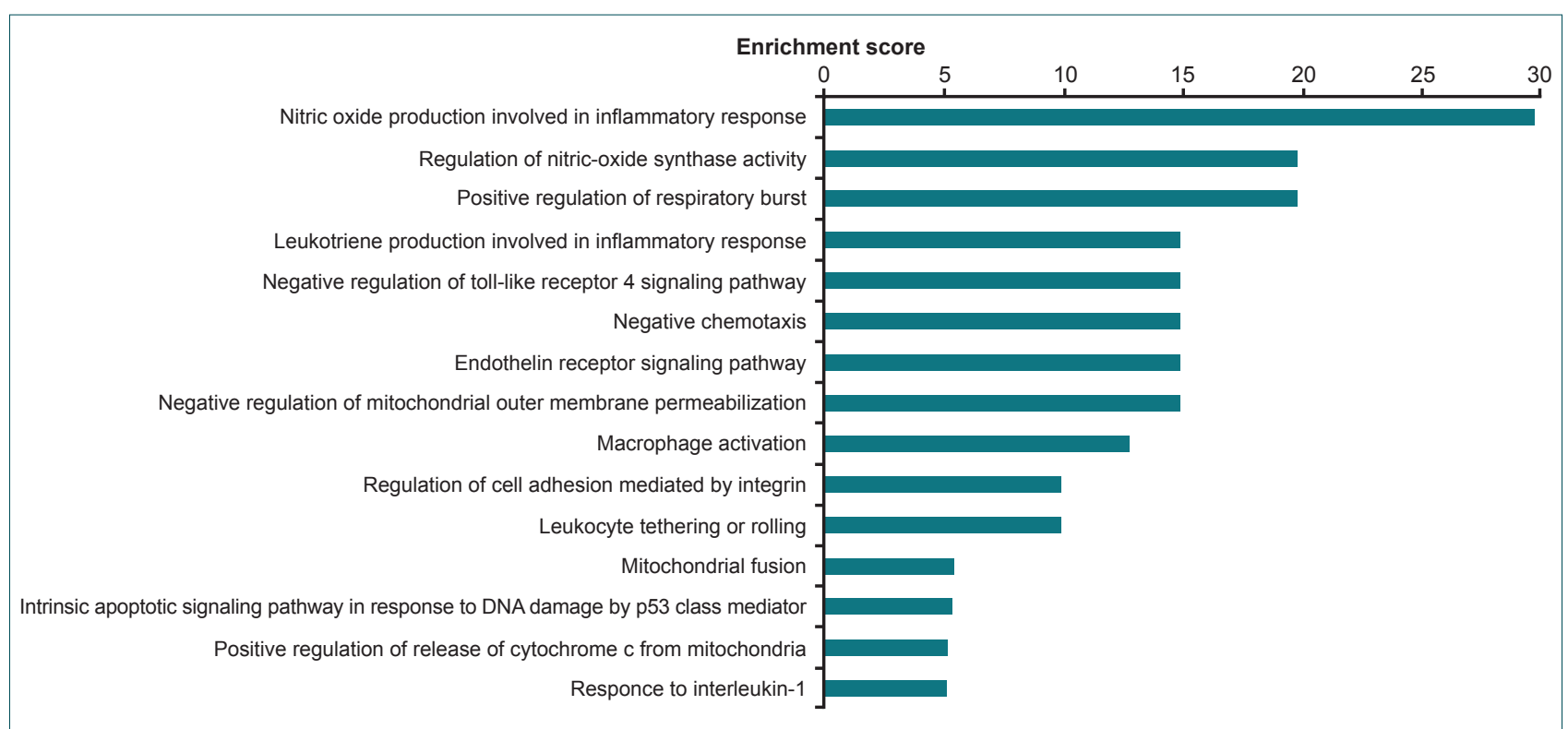

Figure 3. Some of the most related GO biological processes with enrichment score of $>5$. 


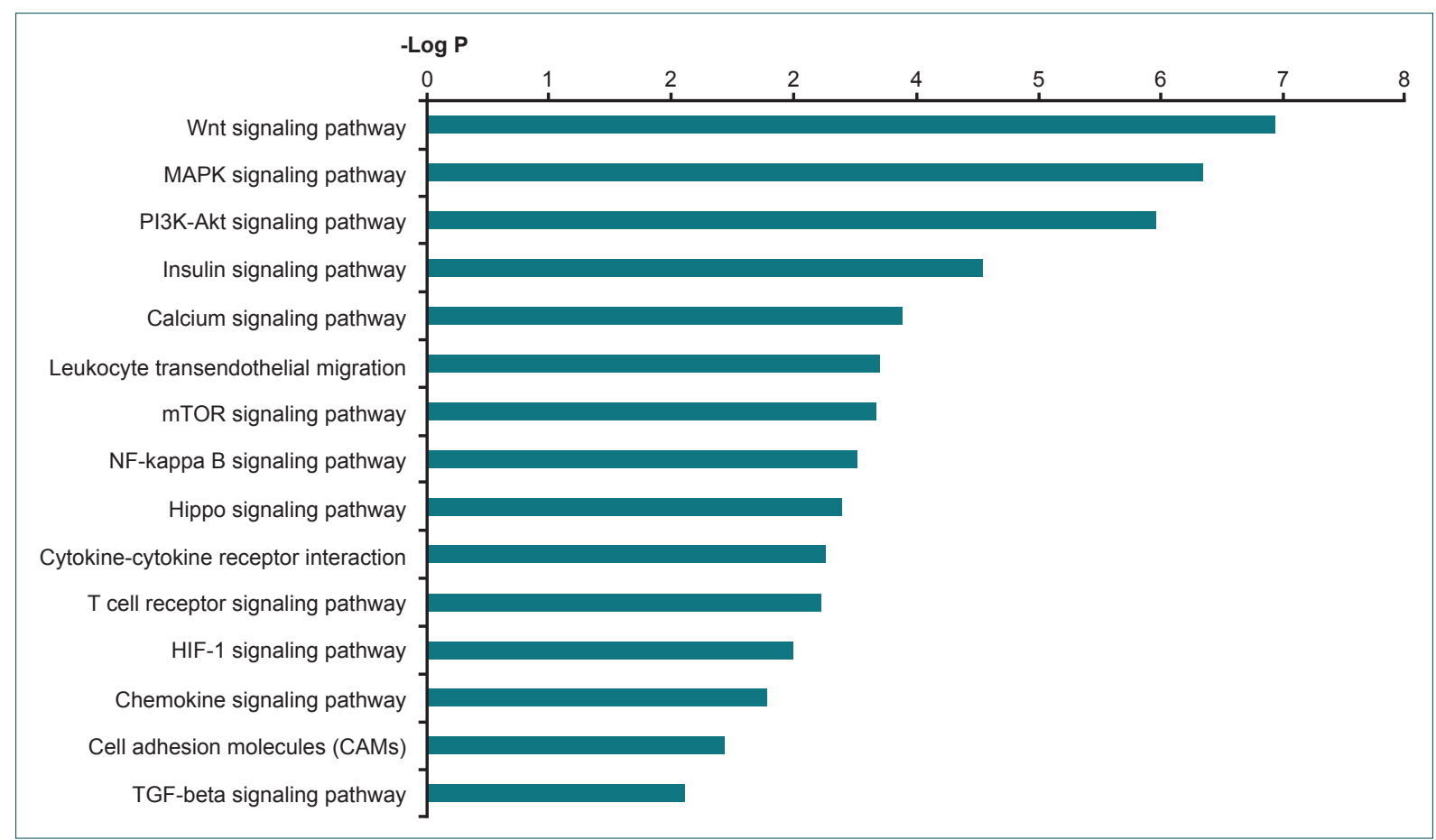

Figure 4. Highly related pathways with $p<0.01$. The $p$-value was calculated with Fisher's exact test and false discovery rate was used to correct the $p$ values.

upregulated and downregulated of these were rno-miR-222$3 p$ and rno-miR-664-I-5p, respectively. The reliability of the array result was confirmed by RT-qPCR. Bioinformatics analysis elucidated that predicted target genes of the differentially expressed miRNAs were mainly enriched in GO biological processes and pathways associated with inflammation and apoptosis. The inflammatory state represented by neutrophil infiltration and the apoptotic condition were confirmed by immunochemical staining of MPO and TUNEL, respectively. Accordingly, miRNAs most likely participate in burn-induced lung injury via regulation of inflammation and apoptosis.

Inflammation and apoptosis have been previously highlighted in ARDS pathophysiology. ${ }^{[24-26]}$ Extensive burns can trigger an excessive inflammatory response resulting in intrinsic alveolar macrophages activation and recruitment of circulating neutrophils. ${ }^{[27]}$ Neutrophils roll around and tether to the endothelium, migrate into the interstitial and alveolar spaces, and produce plenty of cytotoxic substances, including reactive oxygen species and proinflammatory cytokines and enzymes. ${ }^{[28]}$ These substances lead to apoptosis of various functional cells, including capillary endothelial cells and alveolar epithelial cells, resulting in respiratory dysfunction. Our bioinformatics analysis suggests that miRNAs are involved in many of these inflammatory and apoptotic cellular processes. miR-96-5p expression was upregulated in mouse macrophage line RAW264.7 cells after Candida albicans infection. ${ }^{[29]}$ miR96-5p was also upregulated in burn lung tissue and was predicted to play a role in GO_macrophage activation by targeting arginine demethylase and lysine hydroxylase 6 (Jmjd6). The upregulated miR-24-2-5p was predicted to participate in
GO_leukocyte tethering or rolling via targeting vascular cell adhesion molecule-I (Vcam-I). miR-24-2-5p also takes part in the leukocyte transendothelial migration pathway and the cell adhesion molecules (CAMs) pathway by targeting VcamI. CAMs are essential for leukocyte tethering to and rolling around the vascular endothelium, while leukocyte tethering and rolling in turn is the beginning of leukocyte transendothelial migration. Thus, it is possible that miR-24-2-5p contributes to burn-induced lung injury by mediating leukocyte infiltration.

A group of GO biological processes focused on mitochondrial damages and intrinsic apoptosis. miR-22I-3p and miR222-3p were upregulated in the lung tissue in burn cases. $\{1 . I$. [TK] Anlam belirsiz. Yapılan düzenlemeyi kontrol edin\} $X \mathrm{Xue}^{[30]}$ reported that miR-22I-3p and miR-222-3p overexpression in human aortic endothelial cell leads to mitochondrial dysfunction, resulting in cellular apoptosis. Moreover, some of the differentially expressed miRNAs induce apoptosis in lung epithelial cell lines, although it is not clear whether the mechanisms are mitochondrial dependent. ${ }^{[31,32]}$ More information about listed GO biological processes and pathways including the related miRNAs and their target genes is available in the supplementary material.

Our study has some limitations that should be taken into consideration when interpreting the results. The miRNA expression profile was determined at a single time point $(24 \mathrm{~h}$ after injury) rather than observed continuously. While $24 \mathrm{~h}$ after injury was quite an early stage of lung damage, miRNA expression had already changed consistent with their rapid 

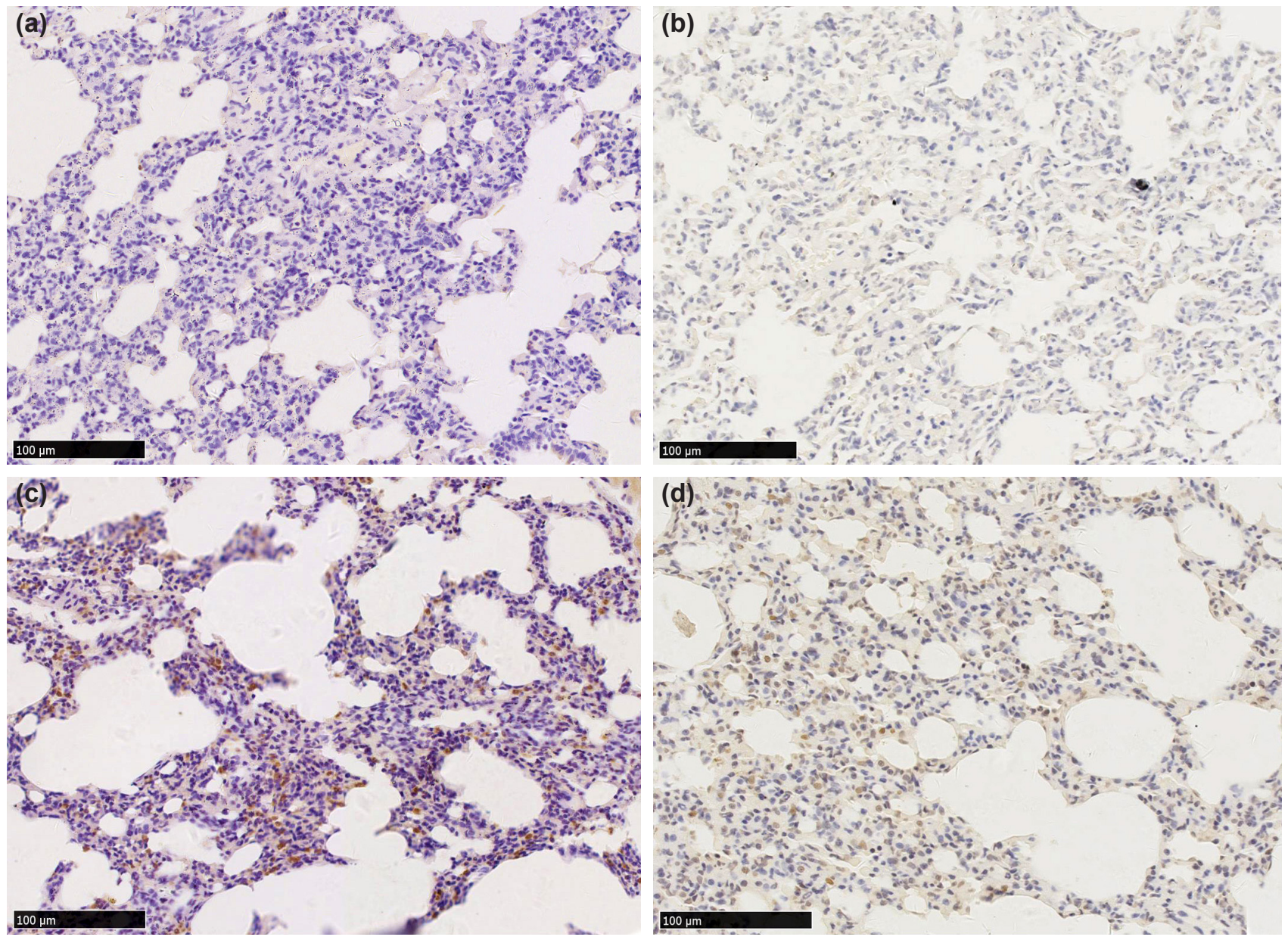

(e)

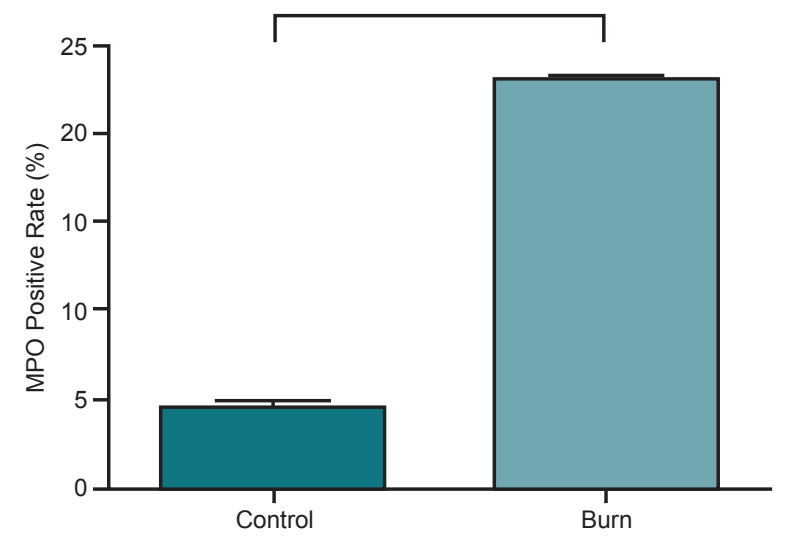

(f)

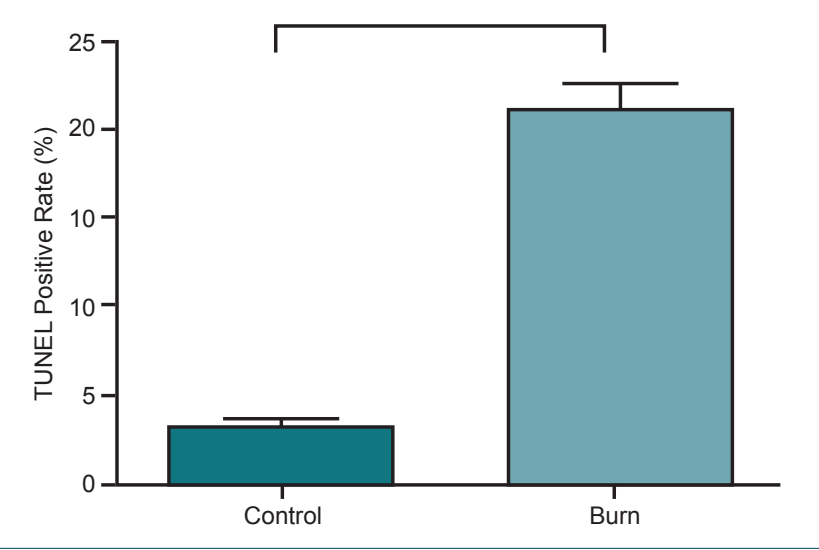

Figure 5. Immunohistochemical staining of MPO and TUNEL. (a) (Sham group) and (c) (burn group) are MPO staining. (b) (Sham group) and (d) (burn group) are TUNEL staining. The original magnification was $20 \times 10$. The scale bar was $100 \mu \mathrm{m}$. (e, f) Are the column charts of quantified positive rate of MPO and TUNEL, respectively. ${ }^{*}$ Comparison between the two groups using t-test, $p<0.05$.

reaction to stimuli. It remains unclear how miRNA expression changes beyond $24 \mathrm{~h}$. The small animal size might also decrease the sensitivity of array hybridization to unknown miRNAs that might be involved in burn-induced lung injury. The current study revealed differentially expressed miRNAs in rat lung in the early post-burns stage. This variable miRNA expression probably participates in the pathophysiology of the lung injury via regulation of inflammation and apopto- sis. The miRNAs may provide targets for further research on the mechanisms and therapies of burn-induced lung injury.

\section{Acknowledgments}

This study was financially supported by the National Natural Science Foundation of China (81571894, 81772067). The authors appreciate Kangchen Biotech Inc. (Shanghai, China) 
and GMINIX Informatics Co., Ltd. (Shanghai, China) for the technological supports.

\section{Conflict of interest: None declared.}

\section{REFERENCES}

1. Endorf FW, Ahrenholz D. Burn management. Curr Opin Crit Care 2011;17:601-5. [CrossRef]

2. Sine CR, Belenkiy SM, Buel AR, Waters JA, Lundy JB, Henderson JL, et al. Acute Respiratory Distress Syndrome in Burn Patients: A Comparisonof the Berlin and American-European Definitions. J Burn Care Res 2016;37:e461-9. [CrossRef]

3. Belenkiy SM, Buel AR, Cannon JW, Sine CR, Aden JK, Henderson JL, et al. Acute respiratory distress syndrome in wartime military burns: application of the Berlin criteria. J Trauma Acute Care Surg 2014;76:8217. [CrossRef]

4. ARDS Definition Task Force, Ranieri VM, Rubenfeld GD, Thompson BT, Ferguson ND, Caldwell E, Fan E, et al. Acute respiratory distress syndrome: the Berlin Definition. JAMA 2012;307:2526-33.

5. Rajasekaran S, Pattarayan D, Rajaguru P, Sudhakar Gandhi PS, Thimmulappa RK. MicroRNA Regulation of Acute Lung Injury and Acute Respiratory Distress Syndrome. J Cell Physiol 2016;231:2097-106.

6. Bernard GR, Artigas A. The definition of ARDS revisited: 20 years later. Intensive Care Med 2016;42:640-2. [CrossRef]

7. Cardinal-Fernández P, Ferruelo A, Esteban A, Lorente JA. Characteristics of microRNAs and their potential relevance for the diagnosis and therapy of the acute respiratory distress syndrome: from bench to bedside. Transl Res 2016;169:102-11. [CrossRef]

8. Yu Y, Chai J, Zhang H, Chu W, Liu L, Ma L, et al. miR-194 Promotes burn-induced hyperglycemia via attenuating IGF-IR expression. Shock 2014;42:578-84. [CrossRef]

9. miRBase. Available at: http://www.mirbase.org/cgi-bin/browse. pl?org=hsa. Accessed Sep 17, 2017.

10. Benz F, Roy S, Trautwein C, Roderburg C, Luedde T. Circulating MicroRNAs as Biomarkers for Sepsis. Int J Mol Sci 2016;17. pii: E78.

11. Bhaskaran M, Xi D, Wang Y, Huang C, Narasaraju T, Shu W, et al. Identification of microRNAs changed in the neonatal lungs in response to hyperoxia exposure. Physiol Genomics 2012;44:970-80. [CrossRef]

12. Xie L, Zhou J, Zhang S, Chen Q, Lai R, Ding W, et al. Integrating microRNA and mRNA expression profiles in response to radiation-induced injury in rat lung. Radiat Oncol 2014;9:111. [CrossRef]

13. Liu S, Liu C, Wang Z, Huang J, Zeng Q. microRNA-23a-5p acts as a potential biomarker for sepsis-induced acute respiratory distress syndrome in early stage. Cell Mol Biol (Noisy-le-grand) 2016;62:31-7.

14. Ke XF, Fang J, Wu XN, Yu CH. MicroRNA-203 accelerates apoptosis in LPS-stimulated alveolar epithelial cells by targeting PIK3CA. Biochem Biophys Res Commun 2014;450:1297-303. [CrossRef]

15. Huang C, Xiao X, Chintagari NR, Breshears M, Wang Y, Liu L. MicroRNA and mRNA expression profiling in rat acute respiratory distress syndrome. BMC Med Genomics 2014;7:46. [CrossRef]

16. Lee SM, Choi H, Yang G, Park KC, Jeong S, Hong S. microRNAs medi- ate oleic acid-induced acute lung injury in rats using an alternative injury mechanism. Mol Med Rep 2014;10:292-300. [CrossRef]

17. Zhang D, Lee H, Cao Y, Dela Cruz CS, Jin Y. miR-185 mediates lung epithelial cell death after oxidative stress. Am J Physiol Lung Cell Mol Physiol 2016;310:L700-10. [CrossRef]

18. Li W, Ma K, Zhang S, Zhang H, Liu J, Wang X, et al. Pulmonary microRNA expression profiling in an immature piglet model of cardiopulmonary bypass-induced acute lung injury. Artif Organs 2015;39:327-35.

19. McAdams RM, Bierle CJ, Boldenow E, Weed S, Tsai J, Beyer RP, et al. Choriodecidual Group B Streptococcal Infection Induces miR-155-5p in the Fetal Lung in Macaca nemestrina. Infect Immun 2015;83:3909-17.

20. Tan KS, Choi H, Jiang X, Yin L, Seet JE, Patzel V, et al. Micro-RNAs in regenerating lungs: an integrative systems biology analysis of murine influenza pneumonia. BMC Genomics 2014;15:587. [CrossRef]

21. Guo ZL, Ren T, Xu L, Zhang L, Yin Q, Wang JC, et al. The microRNAs expression changes rapidly in mice lung tissue during lipopolysaccharideinduced acute lung injury. Chin Med J (Engl) 2013;126:181-3.

22. Li W, Qiu X, Jiang H, Han Y, Wei D, Liu J. Downregulation of miR-181a protects mice from LPS-induced acute lung injury by targeting Bcl-2. Biomed Pharmacother 2016;84:1375-82. [CrossRef]

23. Liu L, Yu Y, Hou Y, Chai J, Duan H, Chu W, et al. Human umbilical cord mesenchymal stem cells transplantation promotes cutaneous wound healing of severe burned rats. PLoS One 2014;9:e88348. [CrossRef]

24. Bhatia M, Moochhala S. Role of inflammatory mediators in the pathophysiology of acute respiratory distress syndrome. J Pathol 2004;202:145-56. [CrossRef]

25. Galani V, Tatsaki E, Bai M, Kitsoulis P, Lekka M, Nakos G, et al. The role of apoptosis in the pathophysiology of Acute Respiratory Distress Syndrome (ARDS): an up-to-date cell-specific review. Pathol Res Pract 2010;206:145-50. [CrossRef]

26. Ogata-Suetsugu S, Yanagihara T, Hamada N, Ikeda-Harada C, Yokoyama T, Suzuki K, et al. Amphiregulin suppresses epithelial cell apoptosis in lipopolysaccharide-induced lung injury in mice. Biochem Biophys Res Commun 2017;484:422-8. [CrossRef]

27. Herold S, Gabrielli NM, Vadász I. Novel concepts of acute lung injury and alveolar-capillary barrier dysfunction. Am J Physiol Lung Cell Mol Physiol 2013;305:L665-81. [CrossRef]

28. Butt Y, Kurdowska A, Allen TC. Acute Lung Injury: A Clinical and Molecular Review. Arch Pathol Lab Med 2016;140:345-50. [CrossRef]

29. Wu CX, Cheng J, Wang YY, Wang JJ, Guo H, Sun H. Microrna Expression Profiling of Macrophage Line Raw264.7 Infected by Candida Albicans. Shock 2017;47:520-30. [CrossRef]

30. Xue Y, Wei Z, Ding H, Wang Q, Zhou Z, Zheng S, et al. MicroRNA$19 b / 221 / 222$ induces endothelial cell dysfunction via suppression of PGC- $1 \alpha$ in the progression of atherosclerosis. Atherosclerosis 2015;241:671-81. [CrossRef]

31. Sun Y, Li L, Xing S, Pan Y, Shi Y, Zhang L, et al. miR-503-3p induces apoptosis of lung cancer cells by regulating $\mathrm{p} 21$ and CDK4 expression. Cancer Biomark 2017;20:597-608. [CrossRef]

32. Zhou Y, Li S, Li J, Wang D, Li Q. Effect of microRNA-135a on Cell Proliferation, Migration, Invasion, Apoptosis and Tumor Angiogenesis Through the IGF-1/PI3K/Akt Signaling Pathway in Non-Small Cell Lung Cancer. Cell Physiol Biochem 2017;42:14314-6. [CrossRef] 
DENEYSEL ÇALIŞMA - ÖZET

\section{Sıçan akciğer dokusunda yanık yaralanmasından sonra erken dönemde mikro RNA ekspresyon profili}

Dr. Donghai Zhang, ${ }^{1}$ Dr. Yang Chang, ${ }^{2}$ Dr. Shaofang Han, ${ }^{2}$ Dr. Longlong Yang, ${ }^{2}$ Dr. Quan Hu, ${ }^{2}$ Dr. Yonghui Yu, ${ }^{2}$ Dr. Lingying Liu, ${ }^{2}$ Dr. Jiake $\mathrm{Chai}^{2}$

${ }^{1}$ Çin PLA Tıp Okulu, Çin PLA Genel Hizmet Hastanesi, Mezunlar Bölümü, Pekin-Çin Halk Cumhuriyeti 2PLA Genel Hizmet Hastanesi, Yanık ve Plastik Cerrahi Bölümü, Pekin-Çin Halk Cumhuriyeti

AMAÇ: Ağır yanık birçok yaralıda akut akciğer hasarına neden olmakla birlikte ilişkin mekanizmalar pek araştııılmamıştır. Mikro RNA'lar (miRNA’lar) sayısız fizyolojik ve fizyopatolojik sürecin önemli düzenleyicidirler. Ancak yanığa bağlı akciğer hasarında miRNA'ların rolü test edilmemiştir.

GEREÇ VE YÖNTEM: Altı sağlıklı erkek Sprague-Dawley sıçanı yanık ve plasebo gruplarına rastgele dağııılı. Yanık olayından 24 saat sonra hematoksilen-eozin (HE) boyasıyla akciğer hasarı değerlendirildi. Farklı oranlarda eksprese edilen miRA'lar dizilim hibridizasyonu ile belirlenmiş, gerçek zamanlı nicel polimeraz zincir reaksiyonuyla (RT-qPCR) doğrulanmıştır. Biyoinformatik analizi ile hedef genler öngörüldü. Potansiyel olarak ilişkili biyolojik süreçler ve yolakları tanımlamak için sırasıyla Gen Ontolojisi (Gene Ontology) ve Kyoto Gen ve Geom Ansiklopedisi (Kyoto Encyclopedia of Genes and Genomes) veri tabanları kullanıldı. Akciğeri nötrofil infiltrasyou ve akciğer apoptozu miyeloperoksidaz immünohistokimyasal boyaması (MPO) ve TUNEL (terminal dezoksinükleotidil transferaz-aracılı dUTP nick- end labeling) yöntemiyle doğrulandı.

BULGULAR: HE boyalı kesitler açıcça akciğer hasarını gösterdi. Toplam 21 'up'regüle ve 3 'down'regüle miRNA saptandı. Bu miRNA'ların hedef genleri en yüksek oranda enflamasyon ve apoptozla ilişkili GO biyolojik süreç ve yolakları içerdi. MPO ve TUNEL boyamasıyla enflamasyon ve apoptoz doğrulandı.

TARTIŞMA: Farklı oranlarda eksprese edilen miRNA'lar enflamasyon ve apoptoza katılarak yanığa bağlı akciğer hasarında en büyük olasılıkla rol oynarlar.

Anahtar sözcükler: Akciğer hasarı/ARDS; apoptoz; enflamasyon; mikroRNA; yanık.

Ulus Travma Acil Cerrahi Derg 2018;24(3):191-198 doi: 10.5505/tjtes.2018.98123 